\title{
Socio-demographic Characteristics of Unmet Need for Family Planning in Maluku, 2015
}

\author{
Evi Pahlawaniati ${ }^{1}$ and Sabarinah B. Prasetyo ${ }^{2}$ \\ ${ }^{1}$ Post-graduate student Faculty of Public Health, Universitas Indonesia, Depok, Indonesia \\ ${ }^{2}$ Faculty of Public Health, Universitas Indonesia, Depok, Indonesia
}

\section{Abstract}

Unmet need for family planning services is the proportion of women of childbearing age who do not want children any more or want to delay childbirth but do not use contraception to prevent pregnancy. In 2012, Maluku was one of the provinces in Indonesia with high unmet need compared to other regions. This study aimed to explore/examine the relationship between unmet need and socio-demographic characteristics. The data take from secondary data of National Socio-Economic Survey (Susenas) in 2015. The number of samples used in the analysis was 3.276 married women of reproductive age. The results showed that of all married women

Corresponding Author:

Evi Pahlawaniati

evi.pahlawaniati61@ui.ac.id

Received: 21 December 2018

Accepted: 23 January 2019

Published: 28 February 2019

Publishing services provided by

Knowledge E

(c) Evi Pahlawaniati and

Sabarinah B. Prasetyo. This

article is distributed under the

terms of the Creative Commons

Attribution License, which

permits unrestricted use and

redistribution provided that the

original author and source are

credited.

Selection and Peer-review under the responsibility of the 3rd IMOPH \& the 1st YSSOPH Conference Committee. of childbearing age, $30.71 \%$ were women with unmet need and the highest level of unmet need was in the district of Southeast West Maluku. Then, 2.422 women who need family planning services divided into groups of met demand and unsatisfied need groups. Multivariable binary logistic regression showed that age group, the age at first marriage, the number of living children, child mortality experience and region simultaneously associated with the status of unmet need for family planning. However, education and work status were not related to the unmet need for family planning significantly. The dominant factor associated with unmet need status for family planning in women were the age at first marriage and region. Most of the reason respondents who did not use contraception were due to adverse side effects on unmet need for spacing and other ideas on the unmet need for limiting.

Keywords: socio-demographic, unmet need, women, Maluku.

\section{Introduction}

The high level of unmet need in family planning is potential for high unwanted pregnancies. Unwanted pregnancy is an essential indicator of maternal and child health, e.g., women with unwanted pregnancies are at risk for unsafe abortions and tend not to pay attention to their pregnancies. The analysis of Demographic and Health Survey (IDHS) in 2012 revealed that mothers who had an unwanted pregnancy had more chance of not having a pregnancy treatment compared to the desired pregnancy or in other words, unwanted pregnancies affect the behavior of antenatal care (ANC) [1]. The study in Europe also revealed that there was an association between unmet need and abortion 
ratios, the higher level of unmet need for family planning made, the higher number of abortions was [2].

Up to now, the number of women with an unwanted pregnancy in the world is relatively high. In 2015, countries in the Southern Asian region had the highest unintended pregnancy that was 24.6 million women, followed by Southern and Eastern Africa of 8.4 million women, Southeast Asia and Oceania of 6.7 million women, Western Africa of 3.5 million women, Northern and Middle Eastern Africa of 2.5 million women, middle Africa of 2 million women, Latin America and Caribbean of 900.000 women and central east Asia of 300.000 women. Whereas in Indonesia, it had 2.629.000 women [3].

Besides impacting unwanted pregnancies, high unmet need for family planning also have an impact on population explosions. Indonesia is a country with the fourth largest population in the world after China, India and the United States. Based on world population data, Indonesia's population in mid-2016 reached 259.4 million people and a population density of 1.104 residents per square kilometer [4]. Having a large population makes Indonesia also face many problems related to the high dynamics of the community.

Unmet need for family planning services defined as the percentage of married women who do not want more children or women who wish to postpone the next birth but do not use contraceptive methods. Women with unmet need for spacing if they are at risk of becoming pregnant, but they do not use contraception and either do not want to become pregnant within the next at least two years or are unsure if or when they want to become pregnant, pregnant with a mistimed pregnancy, postpartum amenorrheic for up to two years following an untimely birth and not using contraception. While women with unmet need for limiting if they are at risk of becoming pregnant, not using contraception, and want no more children, pregnant with an unwanted pregnancy, postpartum amenorrheic for up to two years following an unwanted birth and not using contraception. Infecund women are considered as no unmet need because they are not at risk of becoming pregnant [5]. This measurement is done by comparing the number of women who can not meet the needs of family planning services by the name of childbearing age couple or married women [6]. As an effort to control the population increasing rapidly and the number of unwanted pregnancies, the government conducts a family planning program. One of the issues faced is the high demand for family planning services that not fulfilled (unmet need for family planning services).

From 69 countries that are the focus of the Family Planning 2020 [3], the number of unmet need for family planning estimation by mid-2015 was 133 million women of childbearing age. While the proportion of women with unmet need for family planning services in those countries was $22.5 \%$. Unsatisfied need rate with highest value by region is Central Africa about 37\%, Latin America and Carrebian about 28\%, East and South Africa about 25\%, West Africa about 25\%, North Africa and Middle East about 23\%, South Asia about 22\%, Southeast Asia and Oceania about 19\%, Central and East Asia about $17 \%$ [3].

The increasing trend of unmet need is one of the issues that Indonesia is facing. Results of Performance Monitoring and Accountability (PMA) Indonesia in 2015 showed that unmet need of married women in Indonesia reached $14.4 \%$ with $7.9 \%$ of unmet need 
for limiting and $6.5 \%$ of unmet need for spacing [7]. That number was higher than the Indonesian Demographic and Health Survey (IDHS) in 2012 which was $11.4 \%$ with $6.9 \%$ for limiting and $4.5 \%$ for spacing whereas modern contraceptive rate had increased from 57.9\% in 2012 to 59.5\% in 2015. However, the total demand for family planning also increased from $73.2 \%$ in 2012 to $75.5 \%$ in 2015 that caused the need for family planning that was met by modern contraceptive methods is difficult to improve, even getting down from $79 \%$ in 2012 to $78.8 \%$ in 2015 [7]. The is become government consideration since the target to reduce unmet need rates has not been successful and has a high risk of unwanted pregnancies from a large number of women of childbearing age.

Some studies revealed that there was a relationship between demographic and socioeconomic conditions with the status of whether women meet the needs of family planning services or not (unmet need status). Research conducted by Letamo and Nevaneethem in Botswana stated that there were differences in socio-economic demographic characteristics such as the age of the woman, age at first marriage, number of living children, number of spouses, employment status, education level and exposure of mass media in giving information about family planning [8]. Of course, some of these conditions and reasons were different in each region.

Maluku is one of the provinces in Indonesia having a high unmet need for family planning services. The unmet need of Maluku in IDHS 2012 was 19.2\% (8.1\% for spacing and $11.1 \%$ for limiting). It also showed that there was a big gap between the total wanted fertility rates and the current fertility rates. The overall fertility rate in Maluku was 3.2 while the total wished to fertility rates was only 2.4 [10]. The analysis of women with high-risk groups in Maluku that was a too young group (childbirth age less than 20 years) showed that as much as $60 \%$ of women of childbearing age who were married did not use contraception. Then another high-risk group of women is a too old group (childbirth age more than 34 years) that $71 \%$ of them did not use contraception [11]. Considering the problem of high unmet need for family planning services in Maluku, it is necessary to know information about factors associated with the status of unmet need for family planning services in Maluku.

\section{Methods}

The research design was a cross-sectional quantitative study to see the problem of unmet need for family planning in Indonesia, especially in Maluku. Data extracted from the individual core dataset National Socioeconomic Survey (Susenas) in 2015. The data was taken from BKKBN cooperating with Statistics Indonesia (BPS). The survey collected information related to socio-economic conditions including health, education, fertility, family planning, housing and other socio-economic conditions [12]. This survey was used as a data source to obtain unmet need characteristics up to the district/town level. The total number of married women aged 15-49 in Maluku was 3.276 women. The inclusion criteria of this study were married women, and exclusion criteria that not used in the analysis were women who did not use contraception and were pregnant with a wanted pregnancy, wanted a child soon, and the women included in the infecund group, so that obtained 2.422 married women. 
The outcome variable of this study was unmet need status for family planning. Unmet need status consists of married women with unmet need (unwanted pregnancy, unmet need for spacing and unmet need for limiting) and met demand for family planning services. The explanatory variables were socio-demographic factors that referred to previous research. The research stated that these factors significantly related to the status of unmet need [13]. Mentioned that unmet need was substantially higher in the group of women aged 15-19 years, the number of living children at least one child, live in rural areas, nonmigrants, uneducated, never discuss family planning with health workers either in health facilities or at home, never talk with a spouse, disapproval of women and husband about family planning.

Factors related to the status of unmet need were adjusted to the availability of variables in the secondary data to be studied. Therefore, the explanatory variables that would use in this study were current age, age at first marriage, the number of living children, child mortality experience, education, work status and region of married women.

Data were analyzed using statistical software (STATA version 13.0). Having had been investigated, data were described using cross tabulation between the status of unmet need for family planning and socio-demographic characteristics with the association relationship and chart. See an association relationship, the study was conducted by categorical data analysis with multivariate binary logistic regression test and how much the risk caused to unmet need.

\section{Results}

Overall, from all married women of childbearing age in Maluku, the total demand of family planning in Maluku was $73.91 \%$ while $30.7 \%$ were women with an unmet need which $0.65 \%$ of them were unwanted pregnancies, $9.78 \%$ were unmet need for spacing and $20.27 \%$ for limiting. Figure 1 shows information about the level of family planning needs by the district in Maluku in 2015. The vertical red line represents the boundary of unmet need in Maluku level. The level of unmet need in Maluku in every region was different. Most of the area had a greater unmet need than the provincial level, except Buru, Central Maluku, and Ambon. Southeast West Maluku was the region with the highest level of unmet need.

Information about the distribution of unmet need in married women of childbearing age based on socio-demographic characteristics such as women's age, age at first marriage, number of living children, child mortality experience, education, work status, and region can see in Table 1. Statistical analysis was done by connecting socio-demographic factors with the state of unmet need. Bivariate logistic regression analysis was done first, followed by the last model of multivariate analysis that could see in the previous column on the table. 


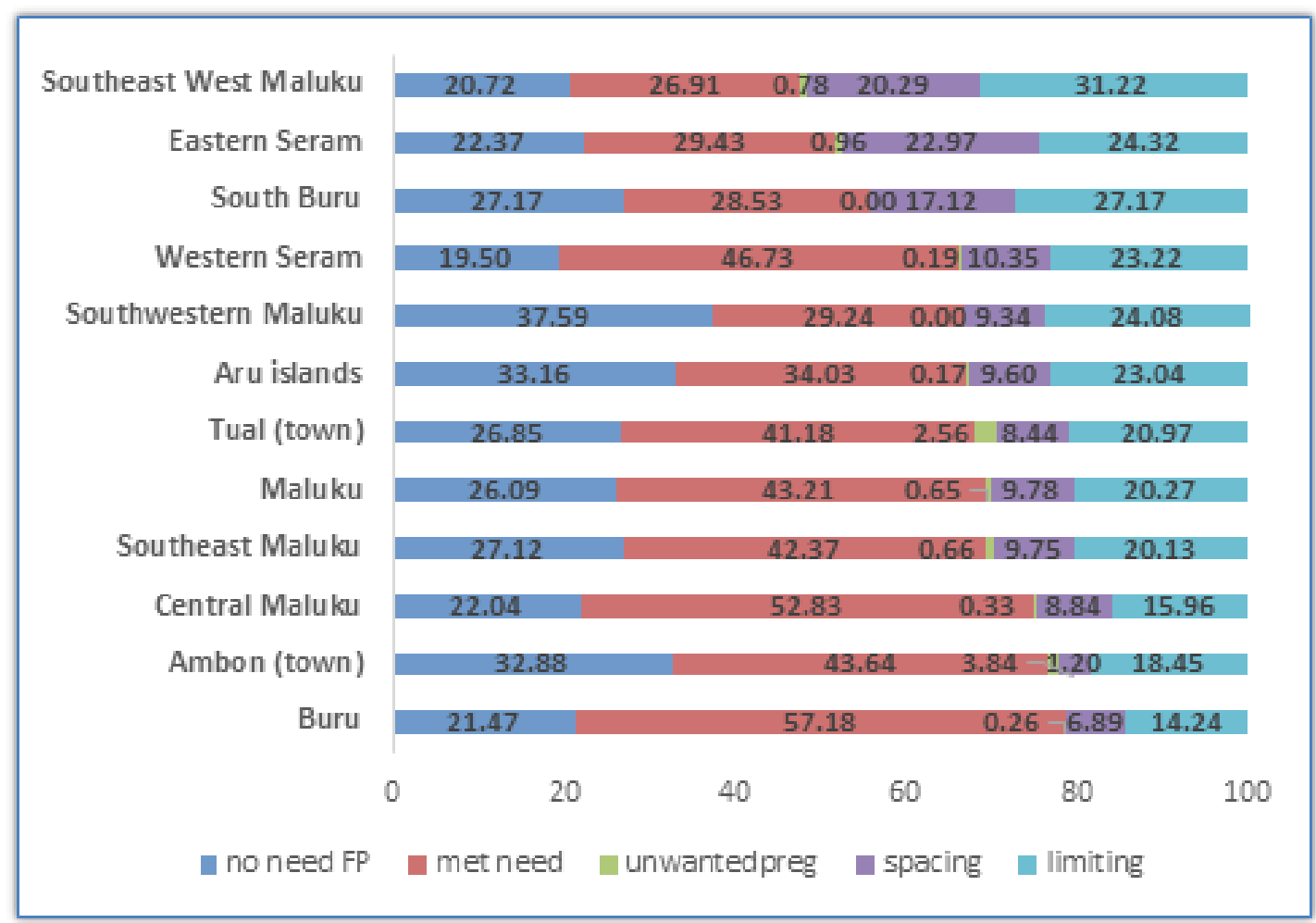

Figure 1: Family Planning Needs in Maluku, 2015.

TABLE 1: Multivariate binary logistic regression of socio-demographic characteristics on unmet need for family planning in Maluku, 2015.

\begin{tabular}{|c|c|c|c|c|c|c|c|c|c|c|c|}
\hline \multirow[t]{2}{*}{ Characteristics } & \multirow[t]{2}{*}{ Number } & \multirow[t]{2}{*}{$\%$} & \multirow{2}{*}{$\begin{array}{c}\% \text { met } \\
\text { need }\end{array}$} & \multicolumn{4}{|c|}{$\%$ unmet need } & \multirow{2}{*}{$\begin{array}{l}\text { \% demand } \\
\text { fulfillment }\end{array}$} & \multirow[t]{2}{*}{ OR } & \multirow[t]{2}{*}{$95 \% \mathrm{Cl}$} & \multirow[t]{2}{*}{ Prob $>F$} \\
\hline & & & & Total & $\begin{array}{c}\text { unwanted } \\
\text { pregnancies }\end{array}$ & spacing & limiting & & & & \\
\hline \multicolumn{12}{|l|}{$\begin{array}{l}\text { Current age } \\
\text { (years) }\end{array}$} \\
\hline $15-19(\mathrm{RC})$ & 56 & 1.72 & 21.06 & 30.77 & 1.52 & 21.06 & 8.19 & 40.63 & & & 0.0001 \\
\hline $20-24$ & 323 & 9.87 & 40.57 & 20.63 & 0.24 & 16.23 & 4.16 & 66.29 & 0.392 & $0.1383456-1.110843$ & \\
\hline $25-29$ & 605 & 18.46 & 48.52 & 22.74 & 0.92 & 15.76 & 6.06 & 68.09 & 0.3373 & $0.1023803-1.111212$ & \\
\hline $30-34$ & 695 & 21.21 & 49.30 & 24.18 & 0.71 & 10.75 & 12.73 & 67.09 & 0.3326 & $0.0845467-1.308386$ & \\
\hline $35-39$ & 666 & 20.32 & 50.27 & 32.07 & 0.54 & 10.18 & 21.35 & 61.05 & 0.419 & $0.1181523-1.485673$ & \\
\hline $40-44$ & 503 & 15.34 & 39.01 & 39.01 & 0.72 & 3.00 & 35.30 & 50.00 & 0.641 & $0.1975981-2.079324$ & \\
\hline $45-49$ & 428 & 13.08 & 24.57 & 48.33 & 0.49 & 0.77 & 47.07 & 33.70 & 1.2063 & $0.3553969-4.094701$ & \\
\hline \multicolumn{12}{|l|}{$\begin{array}{l}\text { Age at first } \\
\text { married }\end{array}$} \\
\hline$<19(\mathrm{RC})$ & 1.204 & 36.75 & 48.79 & 29.79 & 0.41 & 9.63 & 19.75 & 62.08 & & & \\
\hline $20-24$ & 1.397 & 42.63 & 44.51 & 31.78 & 0.91 & 10.37 & 20.50 & 58.35 & 1.3192 & $1.061261-1.639859$ & \\
\hline$>24$ & 675 & 20.62 & 30.58 & 30.14 & 0.53 & 8.83 & 20.77 & 50.36 & 1.6159 & $1.203207-2.170194$ & \\
\hline
\end{tabular}




\begin{tabular}{|c|c|c|c|c|c|c|c|c|c|c|c|}
\hline \multirow{2}{*}{$\begin{array}{l}\text { Characteristics } \\
\text { Number of } \\
\text { living children }\end{array}$} & \multirow{2}{*}{ Number } & \multirow[t]{2}{*}{$\%$} & \multirow{2}{*}{\multicolumn{2}{|c|}{$\begin{array}{c}\% \text { met } \\
\text { need }\end{array}$}} & \multicolumn{3}{|c|}{$\%$ unmet need } & \multirow{2}{*}{$\begin{array}{l}\text { \% demand } \\
\text { fulfillment }\end{array}$} & \multirow[t]{2}{*}{ OR } & \multirow[t]{2}{*}{$95 \% \mathrm{Cl}$} & \multirow[t]{2}{*}{ Prob $>F$} \\
\hline & & & & & & & & & & & \\
\hline$<4(\mathrm{RC})$ & 2376 & 72.52 & 42.84 & 26.79 & 0.50 & 11.44 & 14.85 & 61.52 & & & \\
\hline $4+$ & 900 & 27.48 & 44.19 & 41.13 & 1.09 & 5.42 & 34.62 & 51.79 & 1.1782 & $0.8697172-1.596172$ & \\
\hline \multicolumn{12}{|l|}{$\begin{array}{l}\text { Child mortality } \\
\text { experience }\end{array}$} \\
\hline No (RC) & 2.546 & 84.04 & 48.33 & 31.52 & 0.69 & 10.47 & 20.36 & 60.53 & & & \\
\hline Yes & 483 & 15.96 & 40.95 & 39.13 & 0.63 & 9.72 & 28.78 & 51.14 & 1.2557 & $0.8924767-1.76676$ & \\
\hline \multicolumn{12}{|l|}{ Education } \\
\hline None (RC) & 251 & 7.82 & 40.32 & 39.69 & 0.52 & 13.31 & 25.86 & 50.40 & & & \\
\hline Primary school & 736 & 22.92 & 39.90 & 35.60 & 0.33 & 11.04 & 24.23 & 52.84 & & & \\
\hline $\begin{array}{l}\text { Junior high } \\
\text { school }\end{array}$ & 641 & 19.96 & 46.87 & 28.62 & 0.55 & 9.12 & 18.95 & 62.08 & & & \\
\hline $\begin{array}{l}\text { Senior high } \\
\text { school }\end{array}$ & 1.156 & 35.96 & 45.86 & 28.63 & 0.86 & 8.53 & 19.23 & 61.57 & & & \\
\hline $\begin{array}{l}\text { College/ } \\
\text { university }\end{array}$ & 429 & 13.34 & 38.72 & 24.87 & 0.90 & 10.41 & 13.56 & 60.90 & & & \\
\hline \multicolumn{12}{|l|}{ Work status } \\
\hline Working (RC) & 1.616 & 49.32 & 41.42 & 32.28 & 0.13 & 8.86 & 23.29 & 56.20 & & & \\
\hline Not working & 1.660 & 50.68 & 44.96 & 29.21 & 1.16 & 10.70 & 17.35 & 60.62 & & & \\
\hline \multicolumn{12}{|l|}{ Region } \\
\hline Town & 895 & 27.33 & 43.30 & 24.74 & 1.39 & 4.50 & 18.85 & 63.64 & & & \\
\hline District & 2.381 & 72.67 & 43.18 & 32.97 & 0.37 & 11.78 & 20.82 & 56.70 & 1.3395 & $\begin{array}{c}0.7834648- \\
2.290245\end{array}$ & \\
\hline
\end{tabular}

On the characteristics of the current age group, the lowest demand fulfillment of family planning was in the youngest and the oldest groups. Unmet need for spacing commonly found in the young groups. On the contrary, unmet need for limiting on the older groups was higher than the younger groups. The strength of the relationship seen from the OR stated that women with 20-44 years old had a lower unmet need than women with 15-19 years old. But in the age group of 45-49 years, the unmet need odds were higher 1.21 times than in the age group of 15-19 years. So unmet need in the youngest and oldest group was different with unmet need in between groups.

Characteristics of the first marriage age, the level of demand fulfillment decreased with the increasing early marriage age of women. There were only $30.58 \%$ of women who married above 24 years that could meet the needs from $60.72 \%$ of total demand in family planning. OR of unmet need in the $20-24$ group was 1.32 times higher than the age of fewer than 19 years as a reference while OR of unmet need in more than 24 years the unmet need was 1.62 times higher than the text. Although unmet need was higher in the older group of age at first married than the reference, unmet needwas dominated by limiting type, it indicated that in both groups was considered to have a different unmet need with the group of text to define their birth. 
Some living children consisted of a group of women who had less than four children and had four children or more. The women who had four living children or more fulfilled their needs only $51.79 \%$, that was lower than another group. The women who had four living children or more mostly found in limiting that was 34.62\%. Unlike in the previous group, the distribution of unmet need type in the group with less than four children tended to be similar between unmet need for spacing (11.44\%) and limiting (14.85\%). Overall, women with many children had the odds of unmet need 1.1782 times higher than women with fewer children.

There was $15.96 \%$ women who have experience on the characteristics of child mortality experience. The demand fulfillment in this group was only $51.14 \%$, and the highest type of unmet need was an unmet need for limiting (28.78\%). The unmet need in both groups was different. The women with child mortality experience had unmet need 1.26 times than the women who had never been.

On the characteristics of the region, $72.67 \%$ of respondents were living in the district while $27.33 \%$ were living in town. Total demand for family planning in the area was higher than in the city. Although the respondents in the community need more family planning than in town, the demand fulfillment in the area was only $56.7 \%$ compared with the region in the city (63.64\%). Therefore, unmet need in both types of the part was different each other. Unmet need in district is 1.34 times higher than unmet need in town but both areas dominated by the limiting unmet need.

Furthermore, other characteristics in this study were education and work status of married women of childbearing age. Unlike other demographic characteristics, education and work status not significantly associated with the state of unmet need for family planning and both not included in the last modeling. In other words, there were no differences in unmet need between groups in the characteristics of education and work status.

Overall, the result of multivariate binary logistic regression analysis showed that age group, age at first marriage, number of living children, child mortality experience and region simultaneously associated with the status of unmet need for family planning in married women of childbearing age with a p-value of the model was less than 0.05 . Compared with other characteristics, age at first marriage and the type of region had the most significant relationship with unmet need for family planning due to the highest odds ratio.

Table 2 illustrates unmet need based on the reasons in married women of childbearing age who did not use contraception. The goals divided into several groups that were fertility reasons, disapproval of family planning, not knowing contraception methods, side effects, other ideas and don't know. Overall, the reason for not using contraception in Maluku dominated by the fear of side effects (39.6\%) and other reasons (38.3\%). Generally, the reason for side effects were women with unmet need for spacing (42.2\%) and the other reasons were women with unmet need for limiting birth (38.7\%). 
TABLE 2: The status of unmet need for family planning by the reasons for not using contraception in Maluku, 2015.

\begin{tabular}{|c|c|c|c|c|c|c|c|c|}
\hline \multirow{3}{*}{$\begin{array}{l}\text { Reasons for not using } \\
\text { contraception }\end{array}$} & \multicolumn{6}{|c|}{ Unmet need } & \multicolumn{2}{|c|}{ Total } \\
\hline & \multicolumn{2}{|c|}{ Spacing } & \multicolumn{2}{|c|}{ Limiting } & \multicolumn{2}{|c|}{ unwanted pregnancy } & \multirow[b]{2}{*}{$\mathbf{n}$} & \multirow[b]{2}{*}{$\%$} \\
\hline & $\mathbf{n}$ & $\%$ & $\mathbf{n}$ & $\%$ & $\mathbf{N}$ & $\%$ & & \\
\hline Fertility reasons & 0 & 0.0 & 0 & 0.0 & 4 & 19.0 & 4 & 0.4 \\
\hline $\begin{array}{l}\text { Disapproval of family } \\
\text { planning }\end{array}$ & 36 & 11.2 & 77 & 11.6 & 1 & 4.8 & 114 & 11.3 \\
\hline $\begin{array}{l}\text { Do not know the } \\
\text { contraception method }\end{array}$ & 4 & 1.2 & 12 & 1.8 & 0 & 0.0 & 16 & 1.6 \\
\hline Fear of side effects & 136 & 42.2 & 260 & 39.2 & 3 & 14.3 & 399 & 39.6 \\
\hline Other reasons & 118 & 36.6 & 257 & 38.7 & 11 & 52.4 & 386 & 38.3 \\
\hline Do not know & 28 & 8.7 & 58 & 8.7 & 2 & 9.5 & 88 & 8.7 \\
\hline Total & 322 & 100.0 & 664 & 100.0 & 21 & 100.0 & 1.007 & 100.0 \\
\hline
\end{tabular}

\section{Discussion}

The proportion of unmet need for family planning in women who needed it in Maluku was high. Distribution of unmet need was not the same in every region, and most areas had an unmet need more significant than the unmet need at the provincial level. Efforts to reduce unmet need had done by $B K K B N$ by increasing access to family planning services, promoting safe contraceptive method through various media. However. Those programs had different effects from one region to another. Therefore, it required information about factors associated with the status of unmet need for family planning so that the unmet need could decrease significantly.

This study aimed to determine the relationship between unmet need status and social demographic characteristics. The study showed that social demographic factors associated with the state of unmet need for family planning in Maluku. Those factors were women's age, age at first marriage, number of living children, children mortality experience and region. The significant factors were also similar to the previous studies in Nigeria and Botswana $[8,14]$.

The dominant factors that had the most significant association relationship with the status of unmet need were the age at first marriage and the type of region. Demand satisfaction in women who first married at a younger age was higher than the women who were first married at more than 20 years. Unmet need for spacing in young first marriage age was more senior than older groups. On the contrary, unmet need for limiting was high in the women who were married in over 24 years whereas all of the groups had a large proportion of unmet need for defining. So, it caused the total unmet need were more common in the women who married in 24 years above than the younger age at first marriage. This result was different with study in Ethiopia and Nigeria stating that total unmet need was higher in the younger generation at first marriage $[13,14]$. Different from the previous reviews, in this study, the young age at first age marriage that did not make the total unmet need is higher than the older age at first marriage. 
The reason for women who did not use contraceptive for limiting birth dominated by the fear of side effects and other purposes.

Beside age at first married, another characteristic that had a high association with the status of unmet need was the type of region. Although there was no difference the level of met demand between the women who lived in district and town, total unmet need was higher on women who lived in the district area. It indicated that the women in the district area needed more family planning than the women in town. In district area, unmet need for spacing was almost three times higher than in the city. So, it needed some efforts to reduce unmet need not only for limiting but also an unmet need for spacing that not fulfilled. This result was different from the study in Botswana stating that there was no association between residence and unmet need for family planning whose the type of region divided into rural and urban areas [8]. However, it was similar with the study in Indonesia that there was a difference unmet need between the women who lived in rural and urban with the OR of unmet need was 1.08 higher on women who lived in rural areas [9].

The reason for women who did not use contraception for spacing or limiting birth dominated by the fear of side effects (39.6\%) and other purposes (38.3\%). The fear of side effects means general health concern about using contraceptive methods while other reasons consisted of access, cost, and convenience [15] - the fear of side effects more commonly found on women with unmet need for spacing. Experience of side effects due to contraceptive use made someone refuse to use it again and also influenced others who wanted to use it. While on other reasons, more commonly found on women with unmet need for limiting.

Geographical conditions in Maluku as an archipelago suspected as the leading cause of other reasons like problems in access, cost, and convenience. Low interisland accessibility, high disparities between regions, and the difference of population distribution make unevenlyhealth services to all community in Maluku [16. Therefore, the reinforcement of the family planning service program and proper contraceptive distribution can do as an effort to reduce the unmet need in Maluku. It becomes essential because the unmet need is the most commonly found in women who want to limit their birth. The previous study in Tanaznia showed by increasing in coverage of interventions that focused on selected high impact intervention at lower levels of the health system reduced around 39\% of child mortality [17]. Similar things were also found on the key messages in other articles strengthening the existing community health volunteer platform a need in achieving improved and equitable progress for reproductive, maternal, newborn and child health in Kenya [18]. This way could implement to this situation by covering more family planning intervention in district areas (intervention to address the basic needs, eg, providing skilled health workers, adequate contraceptives and information about safe contraception methods in community levels as needed).

The research data used were not explicitly designed to measure fertility indicators. Therefore, the unmet need calculations in this study different from other fertility surveys and factors related to the status of unmet need were limited to socio-demographic characteristics only. Moreover, the group of women using contraceptives based on their intended use cannot see whether for spacing or limiting births. Besides, there was no 
information about unwanted pregnancy whether it was unwanted pregnancy (limiting) or mistimed pregnancy (spacing) so that this type was separated with other types of unmet need.

\section{Conclusion}

Unmet need for family planning services, either for spacing or limiting among the women who needed it, was high in Maluku. Differences in social demographic characteristics in women affected women's decisions on contraceptive use. These social demographic characteristics include women's age, age at first marriage, number of living children, child mortality experience and region. Among other variables, age at first marriage and type of region had the most significant relationship with unmet need for family planning in Maluku. Unmet need for family planning in women who were old enough at first marriage more likely to be found that women who first married at the age of adolescence and it was also higher on the women who lived in the district than in town. The reasons of respondents who did not use contraception were generally due to side effects and other purposes. The idea of side effects was more likely to be found in women with unmet need for spacing and other reasons commonly in women with unmet need for limiting. By paying attention to the result of the study, it required a segmentation of the program's requirements so the program is on target.

\section{Acknowledgment}

The author would like to thank $B K K B N$ and $B P S$ for its contribution in providing data in this research.

\section{References}

[1] Lisa Indriani Dini; Pandu Riono; Ning Sulistyowati. 2016. "PENGARUH STATUS KEHAMILAN TIDAK DIINGINKAN TERHADAP PERILAKU IBU SELAMA KEHAMILAN DAN SETELAH KELAHIRAN DI INDONESIA (ANALISIS DATA SDKI 2012)." 7(2): 119-33.

[2] Klijzing, Erik. 2000. "Are There Unmet Family Planning Needs in Europe?" Mar/Apr 20(Family Planning Perspective): 74, ProQuest. https://remote-lib.ui.ac.id:6066/docview/224371007/fulltext/ 8BFC685F59E44353PQ/5?accountid=17242, accessed August 23rd, 2017.

[3] FP2020. 2015. FP2020 Commitment to Action, Measurement Annex November 2015. November 2.

[4] Population Reference Bureau. 2016. 2016 World Population Data Sheet With a Special Focus on Human Needs. http://www.prb.org/Publications/Datasheets/2016/2016-world-population-data-sheet. aspx, diunduh 12 Maret 2017.

[5] Badan Pusat Statistik, Badan Koordinasi Keluarga Berencanan Nasional, Departemen Kesehatan, dan Macro International. 2013. Sdki Survei Demografi dan Kesehatan Indonesia 2012.

[6] Badan Kependudukan dan Keluarga Berencana Nasional. 2016. LAPORAN KINERJA INSTANSI PEMERINTAH 2015 BADAN KEPENDUDUKAN DAN KELUARGA BERENCANA NASIONAL. Jakarta. https://www.bkkbn.go.id/po-content/uploads/LAKIP_BKKBN_2016_1.pdf.

[7] PMA 2020 Data and Research. 2015. "PMA 2015/INDONESIA-R1, Performance Monitoring \& Accountability 2020." https://www.pma2020.org/sites/default/files/ID-R1-ID-Brief-v8-2015.12.01_0.pdf, diunduh pada tanggal 10 Maret 2017.

[8] Letamo, Gobopamang, dan Kannan Navaneetham. 2015. "Levels, trends, and reasons for unmet need for family planning among married women in Botswana: a cross-sectional study." BMJ open 5(3): e006603. http://www.pubmedcentral.nih.gov/articlerender.fcgi?artid=4386234\&tool= pmcentrez\&rendertype=abstract. 
[9] Tiara, Anantha Dian. 2011. "Faktor-faktor yang Berhubungan dengan Unmet Need Keluarga Berencana: Analisis SDKI 2007." Universitas Indonesia.

[10] BPS, BKKBN, Kementerian Kesehatan, dan USAID. 2012. Demographic and Health Survey 2012.

[11] Kementerian Kesehatan RI. 2013. "Buletin Jendela Data dan Informasi Kesehatan, Volume 2, Semester II, 2013. Topik Utama: Situasi Keliarga Berencana di Indonesia.” : 12. http://www.depkes.go.id/download. php?file=download/pusdatin/buletin/buletin-kespro.pdf.

[12] BPS. 2016. Indonesia - Survei Sosial Ekonomi Nasional 2015 September ( MSBP ). Jakarta.

[13] Korra, Antenane. 2002. Attitudes Towards Family Planning and Reasons for Nonuse among Women with Unmet Need for Family Planning in Ethiopia. Maryland: ORC Macro.

[14] Bola Lukman. 2016. "SOCIO-DEMOGRAPHIC FACTORS ASSOCIATED WITH UNMET NEED FOR FAMILY PLANNING AMONG WOMEN WHO EXPERIENCED PREGNANCY TERMINATION IN NIGERIA Bola Lukman SOLANKE." 19(3): 112-25.

[15] Westoff, Charles F. 2012. UNMET NEED FOR MODERN CONTRACEPTIVE METHODS DHS ANALYTICAL STUDIES 28. Ed. Bryant Robey. USAID.

[16] Litamahuputty, Vonny, Jeis Montesori, dan JEM. 2015. "Kondisi Geografis Maluku Jadi Kendala Pembangunan Kesehatan." berita satu.com. http://www.beritasatu.com/nasional/332186-kondisi-geografismaluku-jadi-kendala-pembangunan-kesehatan.html.

[17] Afnan-holmes, Hoviyeh, et al. 2015. "Tanzania 's Countdown to 2015: An Analysis of Two Decades of Progress and Gaps For Reproductive, Maternal, Newborn, and Child Health, to Inform Priorities for Post2015." : 396-409. Child health programmes focused on selected high-impact interventions at lower \%OAlevels of the health system (e.g., the community and dispensary levels), August 22nd, 2017.

[18] Keats, Emily C, et al. 2017. "Articles Progress And Priorities For Reproductive, Maternal, Newborn, and Child Health in Kenya: A Countdown to 2015 Country Case Study." The Lancet Global Health 5(8): e78295. http://dx.doi.org/10.1016/S2214-109X(17)30246-2. 